
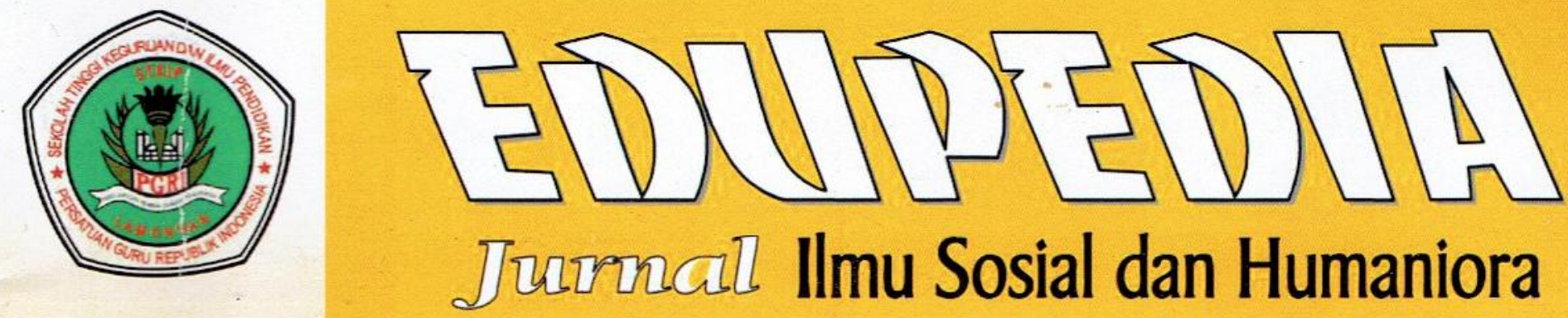

Meningkatan Kemampuan Mengarang Melalui Metode Field Trip Hal. 204-212 Siswa Kelas IV SD Negeri Mendogo;

Oleh: Suparlan

Perumusan Kebijakan Publik dalam Partisipasi Masyarakat;

Hal. $213-219$

Oleh: Sukisno

Penerapan Metode Demonstrasi untuk Meningkatkan Proses Belajar IPA Kelas IX SMP Negeri 3 Ngimbang;

Hal. $220-224$

Oleh: Sugiyanto

Upaya Peningkatan Motivasi Belajar melałui Pendekatan Hal. 225-232 Konstruktivisme Mata Pelajaran IPS di SMP Negeri 3 Ngimbang;

Oleh: Syprapto

Peran Kepemimpinan Dalam Mengatasi Berbagai Konflik Hal.233-242 Internal Dalam Organisasi Pendidikan;

Oleh: Endah Yuliani

Pengembangan Bahan Ajar Kimia Kelas XI SMA Negeri I Hal. 243-253 Karangbinangun Lamougan;

Oleh: Ernawati

Upaya Meningkatkan Kualitas Sumber Dava Manusia Dengan Hal. 254-258 Budaya Literasi;

Oleh: Ratna Nurdiana

Optimalisasi Penerapan Kurikulum 2013 Dalam Proses Belajar Hal. 259- 265 Mengajar;

Oleh: Hadi Suryanto

Pengintegrasian Virus Enterpreneur Melalui Mata Kuliah Hal. 266-272 Kewirausahaan Pada Mahasiswa STKIP PGRI Lamongan;

Oleh: Yayuk Chayatun Machsunah

ISSN: 2407-7550 Volume 2 Nomor 2 Juni $2016 \quad$ Hal. $203-272$

Diterbitkan Oleh:

Pusat Penelitian dan Pengabdian Masyarakat

STKIP PGRI Lamongan, Jalan Sunan Giri No. 35 Lamongan 


\section{DAFTAR ISI} Meningkatan Kemampuan Mengarang Melalui Metode Field Trip Siswa Hal. 204-212
Kelas IV SD Negeri Mendogo;

Oleh: Suparlan

Perumusan Kebijakan Publik dalam Partisipasi Masyarakat;

Hal. $213-219$

Oleh: Sukisno

Penerapan Metode Demonstrasi untuk Meningkatkan Proses Belajar IPA Kelas IX SMP Negeri 3 Ngimbang;

Hal. $220-224$

Oleh: Sugiyanto

Upaya Peninģkatan 1 1otivasi Belajar melalui Pendekatan Konstruktivisme Mata Pelajaran IPS di SMP Negeri 3 Ngimbang;

Hal. $225-232$

Oleh: Suprapto Peran Kepemimpinan Dalam Mengatasi Berbagai Konflik Internal Dalam
Organisasi Pendidikan;

Oleh: Endah Yuliani Pengembangan Bahan Ajar Kimia Kelas XI SMA Negeri I Karangbinangun
Lamongan;

Hal. $243-253$

Oleh: Ernawati

Upaya Meningkatkan Kualitas Sumber Daya Manusia Dengan Budaya Hal. 254-258
Literasi;

Oleh: Ratna Nurdiana

Optimalisasi Penerapan Kurikulum 2013 Dalam Proses Belajar Mengajar;

Oleh: Hadi Suryanto

Hal. $259-265$

Pengintegrasian Virus Enterpreneur Melaiui Mata Kuliah Kewirausahaan Pada Mahasiswa STKIP PGRI Lamongan;

Hal. $266-272$

Oleh: Yayuk Chayatun Machsunah 


\title{
PENGINTEGRASIAN VIRUS ENTERPRENEUR MELALUI MATA KULIAH KEWIRAUSAHAAN PADA MAHASISWA STKIP PGRI LAIMONGAN
}

\author{
Yayuk Chayatun Machsunah \\ STKIP PGRI Lamongan \\ Email: yayuk chayatun@yahoo.co.id
}

\begin{abstract}
ABSTRAK
Sulitnya lulusan universitas lokal memperoleh pekerjaan suäah terlihat dari angka pengangguran terdidik Indonesia yang meningkat setiap tahun. Berdasaikan clata Badan Pusat Statistik (BPS) pada Agustus 2014, di Indonesia ada 9,5 persen (588.660 orang) dari total penganggur yang merupakan alumni perguruan tinggi. Mereka memiliki ijazah diploma tiga atau ijazah strata satu (S-l). Dari jumlah itu, penganggur paling tinggi merupakan lulusan universitas bergelar S-1 sebanyak 495.143 orang. Angka pengangguran terdidik pada 2014 itu meningkat dibandingkan penganggur lulusan perguruan tinggi pada 2013 yang hanya 8,36 persen 1519.288 orang) dan pada 2012 sebesar 8,79 persen ( 645.866 orang). Untuk itu dalam mata kuliah Kewirausahaan semester Genap tahun 2016 ini mahasiswa STKIP PGRI Lamongan prodi Pkn dan Ekonomi dibekali semangat untuk tidak tergantung pada pundak pemerintah dalam penyediaan lapangan pekerjaan, karena STKIP PGRI Lamongan adalah perguruan tinggi yang mencetak sarjana pendidikan yang kebanyakan mahasiswa mindsetnya adalah menjadi guru di sekolah-sekolah negeri atau menjadi guru PNS. Untuk itu dalam mata kuliah kewirausahaan diharapkan ada semacam virus yang menyebar untuk para mahasiswa merubah mindset dari menjadi PNS untuk beralih ke wirausaha. Mahasiswa mulai termotivasi uniuk berwirausaha dan tidak lagi mengandalkan pundak pemerintah untuk penyediaan lapangan pekerjaan. Mahasiswa mulai mempunyai semangat untuk berwirausaha, Mahasiswa tidak takut lagi berwirausaha karena terganjal faltor modal, Mahasiswa tiäak takut gagal dalam berwirausaha, Mahasiswa tidak menganggap wirausaha mengandung resiko yang besar. Didalam mata kuliah kewirausahaan diajarkan tentang teori konsep dasar kewirausahaan meliputi: sikap, kepribadian dan profil seorang wirausaha, pengenalan potensi diri, pengembangan kemampuan manajerial, keberanian mengambil resiko, pengenalan fungsi model kewirausahaan, mengembangkan ide dan analisis peluang usaha, analisis SWOT, pembuatan rancangan usaha. Dengan ini diharapkan semakin banyak sarjana yang berwirausaha atau menjadi enterpreneurship sehingga menjadi mandiri bahkan bisa membuka lapangixn pekerjaan untuk diri sendiri, dan tidak tergantung pemerintah, bahkan bisa membantu untuk menyiapkan lapangan pekerjaan untuk orang lain.
\end{abstract}

Kata Kunci: Enterpreneur, Mata Kuliah Kewirausahaan.

\section{PENDAHULUAN}

Lulusan perguruan tinggi Indonesia sedang mengalami dilema, sebab gelar ijazah pendidikan tinggi yang mereka raih tak lagi jadi jaminan mudah untuk mendapat pekerjaan. Kesulitan mereka terserap dunia kerja semakin bertambah berat, karena mulai 1 Januari tahun ini mereka juga bersaing dengan țenaga kerja asing dari negara-negara ASEAN sebagai dampak berlakunya Masya- rakat Ekonomi ASEAIN (MEA). Sulitnya lulusan universitas lokal memperoleh pekerjaan sudah terlihat dari angka pengangguran terdióik Indonesia yang meningkat setiap tahun. Berdasarkan data Eadan Pusat Statistik (BPS) pada Agustus 2014, di Indo-nesia ada 9,5 persen ( 688.660 orang) dari total penganggur yang merupakan alumni perguruan tinggi. Mereka memiliki jiazah diploma tiga atau ijazah strata satu (S-1). Dari jumlah 
itu, penganggur paling ting-gimerupakan lulusan universitas bergelar S-1 sebaryak 495.143 orang. Angka pengang-guran terdidik pada 2014 itu meningkat disbandingkan penganggr lulusan perguruau tinggi pada 2013 yang hanya 8,36 persen $(619.288$ orang) dan pada 2012 sebesar 8,79 persen (645.866 orang). "Tingkat pengang-guran terbuka Indonesia berdasarkan pendi-cikan yang ditamatkan cukup membaha-yakan," kata mantan Wakil Menteri Pendi-dikan Nasional, Fasli Djalal, pada Kompas, (27/4/2015)

Indonesia saat ini membutuhkan para wirausaha muda untuk dapat mendukung partumbuhan ekoromi negara. Jumlah wirausaha di Indonesia baru mencapai 0,24 persen dari jurnlah penduduk Indonesia yang mencapai 240 juta. Jumlah itu lebih rendah dibandingkan dengan wirausaha di beberapa negara luar yarig tingkat pertumbuhan ekonominya tinggi, seperti Amerika Serikat yang mencapai $11 \%$, Singapura $7 \%$, dan Malaysia $5 \%$. Dengan melitat perbandingan jumlah wirausaha di negara rnaju tersebut, wajar jika pertumbuhan perekonomian di Indonesia masih lambat, meskipun saat ini Indonesia adalah negara dengan tingkat pertumbuhan stabil. Oleh karena itu, pemerintah harus mengembangkan sektor kewirausahaan dan meningkatkan jumlah wirausahawan agar dapat berperan dalam mendukung ekonomi negara. Namun harus diingat, pertumbuhan jumlah wirausahawan harus didukung oleh lembaga pendiclikan, termasuk perguruan tinggi. Pendidikan penting untuk memberi modal dasar bagi para wirausahawan. Melalui jalur pendidikan dapat mengubah pola pikir seseorang urituk menjadikan wirausahawan yang bekerja dengan menggunakan ide dan kreativitas.

Peran perguruan tinggi, dalam hal ini dapat memotivasi para sarjananya menjadi young entrepreneurs, yang merupakan bagian dari salah satu faktor pendorong partumbuhan kewirauschaan. Siklus yang kernudian terjadi adalah dengan meringkatnya wirausahawan dari kalangan sarjana akan mengurangi pengangguran, serta menambah jumlah lapangan pekerjaan. Tidak ada satu pun negara maju tanpa ditopang pertumbuhan entrepreneur. Indonesia harus memperbesar jumlah wirausahawan minimal dua persen dari jumlah penduduk atau sekitar empat juta orang. Semoga pengusaha local akan bertambah, terlebih lagi kalau dimotori oleh sarjana karena itu secara tidak langsung akan berimbas pada sarjana lainnya untuk melakukan hal yang sama yaitu menjadi entrepreneur.

Dengan melihat betapa kebutuhan enterpreneur atau wirausaha di berbagai sektor yang sangat besiar, sudah selayaknya para sarjana untuk tidak menggantungkan cita-citanya untuk menjadi pegawai atau bahkan PNS tetapi lebih termotivasi untuk berusaha sendiri diatas kaki sendiri yang nantinya bisa untuk menghidupi diri sendiri, keluarganya atau bahkan membuka lapangan pekerjaan untuk orang disekitarnya.

\section{KEWIRAUSAHAAN}

Kewirausahaan adalah padanan kata dari entrepreneurship dalam bahasa Inggris, unternehmer dalam bahasa Jerman, ondernemen dalam bahasa Belanda. Sedangkan di Indonesia diberi nama kewirausahaan. Kata entrepreneur berasal dari bahasa Perancis yaitu entreprende yang berarti petualang, pengambil risiko, kontraktor, pengusaha (orang yang mengusahakan suatu pekerjaan tertentu), dan pencipta yang menjual hasil ciptaannya. Entrepreneurship adalah suatu kemampuan untuk mengelola sesuatu yang ada dalam diri Anda untuk dimanfaatkan dan ditingkatkan agar lebih optimal (baik) sehingga bisa meningkatkan taraf hidup Anda dimasa mendatang.

Indonesia entrepreneurial skill untuk bisa menekan sekecil mungkin tingkat kemiskinan yang tinggi. Menngandalkan investor asing untuk membuka lapangan kerja tidaklah cukup, menghimbau kepada perusahaan untuk tidak mem-PHK karyawan atau buruhnya juga sulit diwujudkan. Salah satu cara atau jalan terbaiknya adalah mengandalkan sector pendidikan utnuk mengubah pola piker lulsannya dari berorientasi mencari kerja menjadi mencetak lapangan kerja sendiri alias menjadi wirausahawan mandiri.

Dalam kehidupan sehari-hari, masih banyak oang yang menafsirkan dan memandang bahwa kewirausahaan identik dengan apa yang dimiliki baru dilakukan "usahawan" atau "wiraswasta". Pandangan tersebut tidaklah tepat, karena jiwa dan sikap kewirausahaan (entrepreneurship) tidak ha- 
nya dimiliki oleh usahawan akan tetapi dapat dimiliki oleh setiap orang yang berpikir kreatif dan bertindak inovatif baik kalangan usahawan maupun masyarakat umum seperti petani, karyawan, pegawai pemerintahan, mahasiswa, guru, dan pimpinan organisasi lainnya.

Wirausaha selalu berkomitmen dalam melakukan tugasnya sampai berhasil. Ia tidak setengah-setengah dalam melakukan pekerjaannya. Karena itu, ia selalu tekun, ulet, pantang menyerah sebelum pekerjaannya berhasil. Tindakannya tidak didasari oleh spekulasi melainkan perhitungan yang matang. Ia berani mengambil resiko terhadap pekerjaannya karena sudah diperhitungkan. Oleh sebab itu, wirausaha selalu berani mengambil resiko yang moderat, artinya resiko yang diambil tidak terlalu tinggi dan tidak terlalu rendah. Keberanian menghadapi resiko yang didukung oleh komitmen yang kuat, mendorong wirausaha untuk terus berjuang mencari peluang sampai memperoleh hasil. Hasil-hasil itu harus nyata atau jelas dan objektif, dan merupakan umpan balik (feedback) bagi kelancaran kegiatannya. Dengan semangat optimisme yang tinggi karena ada hasil vang diperoleh, maka uang selalu dikelola secara proaktif dan dipandang sebagai sumter daya bukan tujuan akhir

Beberapa ciri kewirausahaan yang dikemukakan oleh para ahli seperti di atas, secara ringkas dikemukakan oleh Vernon a Musselman (1989:155), Wasty Sumanto (1989), dan Geoffey Meredith (1989:5) dalam bentuk ciri-ciri berikut : (1) Keinginan yang kuat untuk berdiri sendiri.

Kemampuan untuk mengambil resiko. (3) Kemampuan untuk belajar dari pengalaman. (4) Memotivasi diri sendiri. (5) Semangat untuk bersaing. (6) Orientasi pada kerja keras.(7) Percaya pada diri sendiri. (8) Dorongan untuk berprestasi. (9) Tingkat energi yang tinggi. (10) Tegas. (11) Yakin pada kemampuan sendiri.

Dalam mencapai keberhasilannya, seorang wirausaha memiliki ciri-ciri tertentu pula. Dalam "Enirepreneurship and Small Enterprise Development Repor" (1986) yang dikutip oleh M. Scarborough dan Thomas W. Zimmerer (1993:5) dikemukakan beberapa karakteristik kewirausahaan yang berhasil, di antaranya memiliki ciri-ciri: (1) Proaktif, yaitu berinisiatif dan tegas (assertive) (2)Berorientasi pada prestasi yang tercermin dalam pandangan dan bertindak (sees and acts) terhadap peluang, orientasi efisiensi, mengutamakan kualitas pekerjaan, berencana, dan mengutamakan monitoring.(3) Komitmen kepada orang lain, misalnya dalam mengadakan kontrak dan hubungan bisnis.

Keberhasilan atau kegagalan wirausaha sangat dipengaruhi juga oleh sifat dan kepribadian seseorang. The officer of Advocacy of Small Business Administration (1989) yang dikutip oleh Dan Steinhoff dan John F Burgess (1993:37) mengemukakan bahwa kewirausahaan yang berhasil pada umurnnya memiliki sifat-sifat kepribadian

Menurut Ahmad sanusi (1994) ada beberapa kecenderungan profil pribadi wirausaha yang dapat diangkat dari kegiatan sehari-hari, di antaranya: (1) Tidak menyenangi lagi halhal yang sudah terbiasai tetap/sudah teratur/ diatur dan jelas. la selalu bosan dengan kegiatan rutin sehingga timbul harapanharapan dan keinginan untuk selalu berubah, ada tambahan, perigayıan, atau perbaikan mutu (nilai tambah yang berbeda). (2) Makin berani, karena merasa perlu untuk menunjukkan sikap kemandirian atau prakasa atas nama sendiri. (3) Suka berimajinasi dan mencoba menyatakan daya kreativitas serta memperkenalkan hasil-hasilnya kepada pihak lain. (4) Menyctakan suatu prakarsa setelah gagasan awalnya diterima dan dikembangkan, serta dapat dipertanggungjawabkan dari beberapa sudut. Prakarsa clianggap tidak final, bahkan terbuka untuk modifikasi dan perubahan. (5) Sikap hati-hati dan cermat mendorong kesiapan bekerja sama dengan pihak lain yang sama-sama mencari kernajuan dan keuntungan. Akan tetapi, jika perlu, ia harus ada kesiapan untuk bersaing. (6) Ujian, godaan, hambatan, dan hal-hal yang tidak terduga dianggap tantangan untuk mencari berbagai ikhtiar.

Alex Inkeles dan david H. Smith (1974:19-24) adalah salah satu di antara ahli yang mengemukakan tentang kualitas dan sikap orang modern. Menurut Inkeles (1974:24) kualitas manusia modern tercermin pada orang yang berpartisipasi dalam produksi modern yang dinanifestasikan dalam bentuk sikap, ni! di, dan tingkah laku dalam kehidupan sosial. Ciri-cirinya meliputi 
keterbukaan terhadap pengalaman baru, selalu membaca perubahan sosial, lebih realitas te hadap fakta dan pendapat, berorientasi pada masa kini dan masa yang akan datang bukan pada masa lalu, berencana, p๕rcaya diri, memiliki aspirasi, berpendidikan dan mempunyai keahlian, respek, hati-hati, dar memahami produksi.

Orang yang terbuka terhadap pengalaman-pengalaman baru akan lebih siap untuk menanggapi segala peluang, tantangan dan perubahan sosial, misalnya dalam mengubah stardar hidupnya. Orang-orang yang terbuka terhadap ide-ide baru ini merupakan wirausaha yang inovatif dan kreatif yang ditemukan dalam jiwa kewirausaharn. Menurut Yurgen Kockia (1975), "Pandangan yang luas dan dinamis serta kesediaan untuk pembaharuan, bisa lebih cepat berkembang dalam lapangan industri, tidak lepas dari suatu latar belakang pendidikan, pengalarnan perjalanan yang banyak" (Yuyun Wirasasmita, (1982:44). Dalam konteks ini, juga dijumpai perpaduan yang nyata antara usaha perdagangan yang sistematis dan rasional dengan kemampuan bereaksi terhadap kesempatan-kesempatan yang didasari keberanian berusaha. Wirausaha adalah kepribadian unggul yang mencerminkan budi yang luhur dan suatu sifat yang pantas diteladani, karena atas dasar kemampuanrya sei diri dapat melahirkan suatu sumbangsih dan karya untuk kernajuan kemanusian yang berlandaskan kebenaran dan kebaikan.

Seperti telah diungkapkan bahwa wirausaha sebenamya adalah seorang inovator atau individu yang mempunyai kemampuan naluriah untuk melihat bendaberida materi sedemikian rupa yang kemudian terbukti benar, mempunyai semangat dan kemampuan serta pikiran untuk menaklukkan cara berpikir yang tidak berubah, dan mempunyai kemampuan untuk bertahan terhadap oposisi sosial (Heijrachman Ranupandoyo, 1982;1). Wirausaha berperan dalam mencari kombinasi-kombinasi baru yang merupakan gabungan dari lima proses inovasi, yaitu menemukan pasarpasar baru, pengenalan barang-barang baru, metode produksi baru, sumber-sumber penyediaan bahan-bahan mentah baru, serta organisasi industri baru. Wirausaha merupakan
Inovator yang dapat menggunakan kemampuan untuk mencari kreasi-kreasi baru. Dalam perusahaan, wirausaha adalah seorang inisiator atau organisator penting suatu perusahaan. Menurut Dusselman (1989:16), seseorang yang memiliki jiwa kewirausahaan ditandai oleh pola-pola tingkah laku sebagai berikut: (1) Inovasi, yaitu usaha untuk menciptakan, menemukan dan menerima ide-ide baru. (2) Keberanian untuk menghadapi resikop, yaitu usaha untuk menimbang dan menerima resiko dalam pengambilan keputusan dan dalam menghadapi ketidakpastian. (3) Kemampuan manajerial, yaitu usaha-usaha yang dilakukan untuk melaksanakan fungsi-fungsi manajemen, meliputi (a) usaha perencanaan, (b) usaha untuk mengkoordinir, (c) usaha untuk menjaga kelancaran usaha, (d) usaha untuk mengwasi dan mengevaluasi usaha. (4) Kepemimpinan, yaitu usaha memotivasi, melaksanakan, dan mengarahkan tujuan usaha.

Telah dikemukakan di atas bahwa wirausaha adalah inovator dalam mengombinasikan sumber-sumber bahan baru, teknologi baru, metode produksi baru, akses pasar baru, dan pangsa pasar baru (Schumpeter, 1934). Oleh Ibnu Soedjono (1993) perilaku kreailf dan inovatif tersebut dinamakan "entrepreneurial action", yang ciri-cirinya (1) selalu mengamankan investasi terhadap risiko, (2) mandiri, (3) berkreasi menciptakan nilai tambah, (4) selalu mencari peluang, (5) berorientasi ke masa depan.

Perilaku tersebut dipengaruhi oleh nilai-niiai kepribadian wirausaha, yaitu nilainilai keberanian menghadapi risiko, sikap positip, dan optimis, keberanian mandiri, dan memimpin, dan kemauan belajar dari pengalaman. Keberhasilan atau kegagalan wirausaha sangat dipengaruhi oleh berbagai faktor baik eksternal maupun internal. Menurut Sujuti Jahja (1977), faktor internal yang berpengaruh adalah kemauan, kemampuan, dan kelemahan. Sedangkan faktor yang berasal dari eksternal diri perlaku adalah kesempatan atau peluang.

Dengan mengetahui tentang lebih jauh kewirausahaan diharapkan para mahasiswa terlecut untuk terjun ke dalam dunia ini sedini mungkin. Tidak ada salahnya bila dimulai sejak dibangku kuliah. Memulai dengan hal kecil berwirausaha tanpa modal 
dengan memanfaatkan fasilitas oniine media sosial. Memulai dengan membiasakan menulis secara komersil di media massa yang akan menghasilkan honor atau berwirausaha di bidang lainnya yang tidak mengganggu waktu kuliah. Berwirausaha tidak harus dengan modal besar untuk memulai. Banyak hal yang perlu dipelajari sehingga mahasiswa semakin tau bahwa modal bukan satu-satu nya faktor untuk memulai sebuah usaha.

\section{MAHASISWA STKIP PGRI LAMONGAN}

Mahasiswa STKIP PGRI Lamongan yang mengikuti mata kuliah kewirausahaan adalah jurusan $\mathrm{PKn}$ dan Ekonomi sejumlah 35 orang. Mata kuliah kewirausahaan meliput: : teori konsep dasar kewirausahaan yaitu sikap, kepribadian dan profil seorang wirausaha, pengenalan potensi diri, perigembangan kemampuan manajerial, keberanian mengambil resiko, pengenalan fungsi model kewirausahaan, mengembangkan ice dan analisis peiuang usaha, analisis SWOT, pembuatan rancangan usaha. Dengan materi ini diharapkan mahssiswa terlecut untuk memulai berwirausaha dan paham secara dasar sebagai seorang wirausaha. Mata kuliah ini 3 SKS dalam 16 kali pertemuan, 2 kali pertemuan untuk UTS dan UAS. Jadi praktis adia 14 tatap muka untuk mengupas tuntas tentang kewirausahaan. Untuk mengetahui apakah mahasiswa telah mempunyai semangat untuk berwirausaha berikut ini hasil penelitian awal yang akan dikembangkan pada penelitian-penelitian yang akan datang:

\begin{tabular}{|c|c|}
\hline Apakah mahasiswa mempunyai cita-cita untuk menjadi guru PNS setelah lulus nanti? \\
\hline $\begin{array}{c}\text { Sebelum pelaksanaan pembelajaran mata } \\
\text { kuliah Kewirausahaan } \\
\text { (mahsiswa) }\end{array}$ & $\begin{array}{c}\text { Setelah pelaksanaan pembelajaran mata kuliah } \\
\text { Kewirausahaan } \\
\text { (mahasiswa) }\end{array}$ \\
\hline 35 & $\frac{7}{2}$ \\
\hline
\end{tabular}

Seluruhnya atau $100 \%$ mahasiswa mengatakan bahwa setelah lulus kuliah nanti mereka bercita-cita untuk menjadi guru PNS, hal itu sesuai hasil angket yang disebarkan kepada 35 mahasiswa jurusan PKn dan Ekonomi yang mengikuti mata kuliah kewirausahaan. Setelah 14 kali pertemuan dan angket kembali disebarkan hanya terdapat 7 mahasiswa $(20 \%)$ yang tetap mengatakan bercita-cita inenjadi guru PNS ketika lulus kuliah nanti.

\begin{tabular}{|c|c|}
\hline \multicolumn{2}{|c|}{ Apakah mahasiswa mempunyai semangat untuk berwirausaha? } \\
\hline $\begin{array}{c}\text { Sebelum pelaksanaan pembelajaran mata } \\
\text { kuliah Kewirausahaan } \\
\text { (mahasiswa) }\end{array}$ & $\begin{array}{c}\text { Setelah pelaksanaan pembelajaran riata kuliah } \\
\text { Kewirausahaan } \\
\text { (mahasiswa) }\end{array}$ \\
\hline 23 & 28 \\
\hline
\end{tabular}

Terdapat $23(65 \%)$ mahasiswa mengatakan mempunyai semangat untuk berwirausaha, hal itu sesuai hasil angket yang disebarkan kepada 35 mahasiswa jurusan PKn dan Ekonomi yang mengikuti mata kuliah kewirauschaan. Setelah 14 kali pertemuan dan angket kembali disebarkan terdapat 28 mahasiswa $(80 \%)$ yang mengatakan semangat untuk berwirausaha setelah lulus kuliah nanti.

\begin{tabular}{|c|c|}
\hline \multicolumn{2}{|c|}{ Apakah tidak tertarik berwirausaha karena terganjal modal??? } \\
\hline $\begin{array}{c}\text { Sebelum pelaksanaan pembelajaran mata } \\
\text { kuliah Kewirausahaan } \\
\text { (mahasiswa) }\end{array}$ & $\begin{array}{c}\text { Seteiah pelaksanaan pembelajaran mata kuliah } \\
\text { Kewirausahain } \\
\text { (mahasiswa) }\end{array}$ \\
\hline 35 & 7 \\
\hline
\end{tabular}


Seluruhnya atau $100 \%$ mahasiswa mengatakan bahwa tidak tertarik berwirausaha dikarenakan terganjal modal, hal itu sesuai hasil angket yang disebarkan kepada 35 mahasiswa junusan PKn dan Ekonomi yang mengikuti mata kuliah kewirausahaan. Setelah 14 kali pertemuan dan angket kembali disebarkan hanya terdapat 7 mahasiswa $(20 \%)$ yang tetap mengatakan tidak berwirausaha karena terganjal modal.

\begin{tabular}{|c|c|}
\hline \multicolumn{2}{|c|}{ Apakah tidak berwirausaha karena takut gagal? } \\
\hline $\begin{array}{c}\text { Sebelum pelaksanaan pembelajaran mata } \\
\text { kui iah Kewirausahaan } \\
\text { (mahasiswa) }\end{array}$ & $\begin{array}{c}\text { Setelah pelaksanaan pembelajaran mata kuliah } \\
\text { Kewirausahaan } \\
\text { (mahasiswa) }\end{array}$ \\
\hline 35 & 7 \\
\hline
\end{tabular}

Seluruhnya atau $100 \%$ mahasiswa mengatakan bahwa tidak tertarik berwirausaha karena takut gagal, hal itu sesuai hasil angket yang disebarkan kepada 35 mahasiswa jurusan $\mathrm{PKn}$ dan Ekonomi yang mengikuti mata kuliah kewirausahaan. Setelah 14 kali pertemuan dan angket kembali disebarkan hanya terdapat 7 mahasiswa $(20 \%)$ yang tetap mengatakan tidak berwirausaha karena takut gagal.

\begin{tabular}{|c|c|}
\hline \multicolumn{2}{|c|}{ Apakah menganggap berwirausaha mengandung resiko yang besar? } \\
\hline $\begin{array}{c}\text { Sebelurn pelaksanaan pembelajaran mata } \\
\text { kuliah Kewirausahaan } \\
\text { (mahasiswa) }\end{array}$ & $\begin{array}{c}\text { Setelah pelaksanaan pembelajaran mata kuliah } \\
\text { Kewirausahaan } \\
\text { (mahasiswa) }\end{array}$ \\
\hline
\end{tabular}

Seluruhrya atau $100 \%$ mahasiswa mengatakan bahwa tidak tertarik berwirausaha karena mengganggap berwirausaha mengandung resiko yang besar, hal itu sesuai hasil angket yang disebarkan kepada 35 mahasiswa jurusan PKn dan Ekonomi yang mengikuti mata kuliah kewirausahaan. Setelah 14 kali pertemuan dan angket kembali disebarkan hariya terdapat 2 mahasiswa. $(5 \%)$ yang tetap mengatakan tidak berwirausaha karena menganggap berwirausaha mengandung resiko yang besar.

\section{KESIMPULAN .}

Keberhasilan atau kegagalan wirausaha sangat diper:ganuhi oleh sifat dan kepribadian seseorang The officer of Advocacy of Small Business Administration. bahwa kewirausahaan yang berhasil pada umumnya memiliki sifat-sifat kepribadian. Seperti telah diungkapkan bahwa wirausaha sebenarnya acalah seorang inovator atau individu yang mempunyai kemampuan naluriah untuk melihat benda-benda materı sedemikian rupa yang kemudian terbukti benar, mempunyai semangat. Para ahli mengemukakan bahwa seseorang memiliki minat berwirausaha karena adanya suatu motif tertentu, yaitu motif berprestasi (achievement motive). Motif berprestasi ialah suatu nilai sosial yang menekankan pada hasrat untuk mencapai yang terbaik guna mencapai kepuasan secara pribadi. Mata kuliah kewirausahaan ini didapatkan hasil : (1) Mahasiswa mulai termotivasi untuk berwirausaha dan tidak lagi mengandalkan pundak pemerinta's untuk penyediaan lapangan pekerjaan. Ini dapat dilihat bahwa sebelum mata kuliah ini berlangsung 100\% mahasiswa mengatakan ingin menjadi guru PNS, dan setelah 14 kali pertemuan dalam perkuliahan berkurang menjadi $20 \%$ mahasiswa yang tetap ingin menjadi guru PNS. (2) Mahasiswa mulai mempunyai semangat untuk berwirausaha, hal ini dapat dilihat sebelum perkuliahan berlangsung $65 \%$ mahasiswa menyatakan mempunyai semangat untuk berwirausaha dan setelah 14 kali pertemuan dalam perkuliahan jumlah mahasiswa yang menyatakan bersemangat untuk berwirausaha menjadi $80 \%$ dari jumlah total mahasiswa yang mengikuti mata kuliah 
kewirausahaan yaitu sebanyak 35 mahasiswa. (3) Mahasiswa tidak takut lagi berwirausaha karena terganjal faktor modal, hal ini bisa dilihat sebelum pelaksanaan perkuliahan semua mahasiswa mengatakan bahwa tidak berwirausaha karena mereka takut tidak ada biaya atau modal untuk mengawali berwirausaha. Tetapi setelah perkuliahan berlangsung hanya ada $20 \%$ mahasiswa yang men yatakan tidak berwirausaha karena terganial faktor modal. (4) Mahasiswa tidak takut gagal dalam berwirausaha, hal ini dapat dilihat bahwa sebelum perkuliahan berlangsung semua mahasiswa menyatakan takut gagal dalam berwirausaha. Tetapi setelah berlangsungnya perkuliahan terdapat $20 \%$ mahasiswa yang masih takut gagal berwirausaha. (5) Mahasiswa tidak menganggap wirausaha mengandung resiko yang besar. Ini berdasarkan angket yang disebarkan sebelum kuliah berlangsung semua mahasiswa mengatakan bahwa wirausaha mengandung resiko yang sangat besar. Tetapi setelah berlangsungnya perkuliahan jumlah mahasiswa yang menganggap berwirausaha mengandung resiko yang besar, tinggal $20 \%$ dari total 35 mahasiswa

\section{DAFTAR PUSTAKA}

Hendro. Dasar-dasar Kewirausahaan. Jakarta : Penerbit Erlangga. 2011.

Kasali Rhenald. Modul Kewirausahaan. Jakarta Selatan : PT Mizan Publika. 2010. Kompas, $(27 / 4 / 2015)$ hal 2

Justin G Longecker, Kewirausahaan, Manajemen Usaha Kecil. Yogyakarta : Salemba Empat. 2000.

Mas'ud Machfoedz, Kewirausahaan, Suatu Pendekatan Kontemporer, Yogyakarta: UPP AMP YKPN. 2004. 